\title{
El cocodrilo en su laberinto
}

\section{The crocodile in its labyrinth}

\author{
F. N. $\operatorname{Diaz}^{1} \quad$ L. A. Miquelini ${ }^{1}$ \\ ${ }^{1}$ Servicio de Diagnóstico por Imágenes, Hospital Italiano de Buenos \\ Aires, Ciudad Autónoma de Buenos Aires, Argentina
}

Rev Argent Radiol 2020;84:80.

Así como en la novela El general en su laberinto de Gabriel García Márquez se muestra al General Simón Bolívar mentalmente exhausto, de esta manera se sienten los estudiantes de Anatomía y a veces los residentes de Diagnóstico por imágenes, al enfrentarse a las estructuras que componen el oído interno.

La similitud observada entre el laberinto óseo en un corte coronal de tomografía computada y la figura de un cocodrilo con la boca abierta es un hecho interesante. Esta semejanza representa además un recurso didáctico, útil para la enseñanza de su anatomía normal, en el cual se incluyen reglas mnemotécnicas.

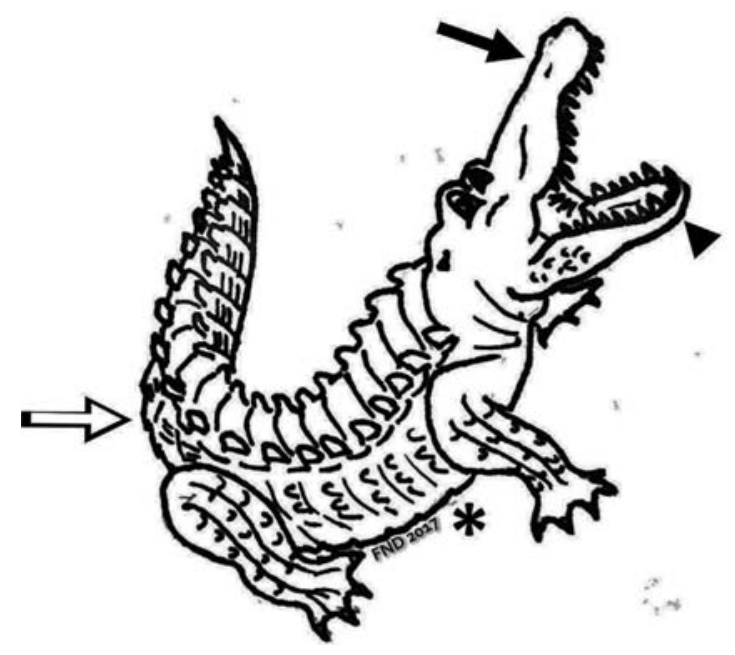

DOI https://doi.org/

10.1016/j.rard.2017.06.002. ISSN 1852-9992.
Address for correspondence F. N. Diaz, Servicio de Diagnóstico por Imágenes, Hospital Italiano de Buenos Aires, Ciudad Autónoma de Buenos Aires, Argentina (e-mail: facundo.diaz@hospitalitaliano.org. ar; facundondiaz@gmail.com).

En la analogía entre ambas imágenes la mandíbula superior es el conducto semicircular superior (flechas negras), la mandíbula inferior que se orienta lateralmente conforma el conducto semicircular lateral (cabezas de flecha), el vientre del reptil se relaciona con el vestíbulo (flechas blancas) y la cola es la cóclea (asteriscos).

De esta forma, podemos reforzar el aprendizaje de una estructura anatómica minúscula y compleja gracias a la ayuda de este simpático animal.

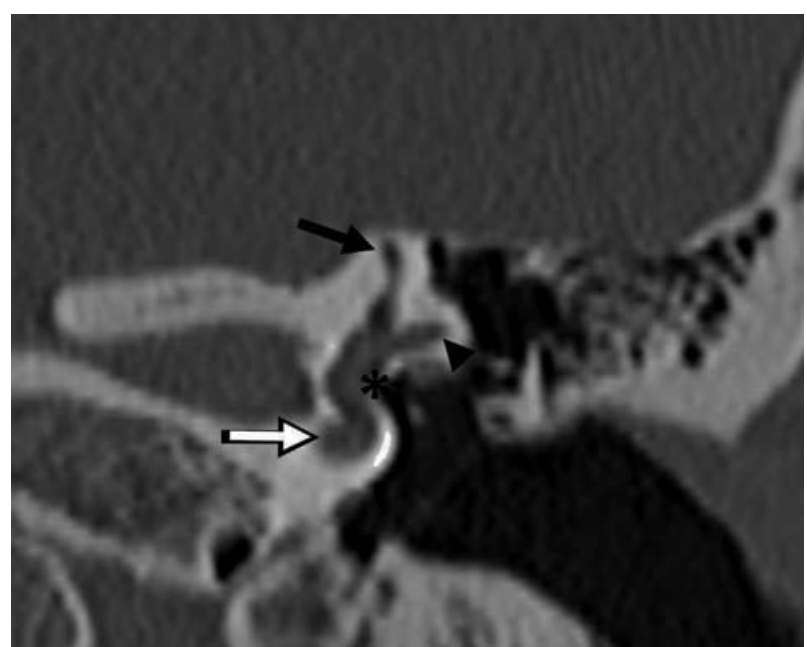

Copyright (c) 2020, Sociedad Argentina de Radiología. Publicado por Thieme Revinter Publicações Ltda., Rio de Janeiro, Brazil. Todos los derechos License terms reservados. 